Article

\title{
POPULATION STRUCTURE OF Heteropsis spp. Kunth (TITICA VINE) IN THE TAPAJÓS NATIONAL FOREST, PARÁ-BRAZIL
} Lizandra Elizeário dos Santos $2^{*} \odot$, João Ricardo Vasconcellos Gama ${ }^{3} \odot$, Andrea Araújo da Silva ${ }^{4} \odot$, and
Marcela Gomes da Silva ${ }^{5} \odot$

\footnotetext{
${ }^{1}$ Received on 29.04.2019 accepted for publication on 14.10.2019.

${ }^{2}$ Universidade Federal Rural da Amazônia,Graduado em Ciências Florestais,Belém,PA-Brasil. E-mail: <lizandraeliziari@hotmail.com>.

${ }^{3}$ Instituto de Biodiversidade e Floresta, Santarém, PA-Brasil. E-mail: <jrvgama@gmail.com>.

${ }^{4}$ Universidade Federal do Oeste do Pará, Programa de Pós-Graduação em Saúde e Qualidade de Vida, Santarém, PA- Brasil. E-mail: $<$ florestalandrea@gmail.com>.

${ }^{5}$ Instituto de Ciências Agrárias,Belém,PA-Brasil. E-mail: <marcela.gsilva@gmail.com> .

*Corresponding author.
}

\begin{abstract}
The objective of the present study was to analyze the ecological aspects of Heteropsis spp. Kunth (titica vine) in an area maintained under forest management conditions. The study was carried out in the Tapajós National Forest, Pará state, Brazil, at Annual Production Unit 11. For the inventory of trees hosting titica vine, 206.25 hectares were covered. The parameters recorded were diameter at breast height - DBH (1.30 $\mathrm{m}$ above the soil), total height $(\mathrm{Ht})$, regional name and geographical coordinates. The mature and immature aerial roots of titica vine were counted and the mass of mature roots with and without bark was collected and measured. The density of the host trees in different class centers of DBH and Ht was related. The ratio between the DBH and Ht of the host trees and the mass of mature root with bark of the titica vine was calculated. Spatial distribution was based on Ripley's K function. A total of 337 trees were inventoried as hosts, with average density of 1.65 trees.ha ${ }^{-1}$, distributed in 88 species. Trees with $\mathrm{DBH}<30 \mathrm{~cm}$ were the ones that host most titica vines. Trees with $10 \mathrm{~m} \leq \mathrm{Ht}<15 \mathrm{~m}$ host more titica vines when compared to trees with $\mathrm{Ht} \geq 25 \mathrm{~m}$. Trees with higher DBH and Ht have the highest number of titica vine roots. The individuals of titica vine had 585 roots. $\mathrm{ha}^{-1}$, leading to an average production of $2.1 \mathrm{~kg}^{\mathrm{h}} \mathrm{ha}^{-1}$ of titica vine with bark, declining after processing to $0.6 \mathrm{~kg}$. $\mathrm{ha}^{-1}$. It was concluded that the titica vine has no preference for host tree species and that the spatial distribution tends to be aggregated.
\end{abstract}

Keywords: Hemiepiphyte; Extractivism; Spatial distribution

\section{ESTRUTURA POPULACIONAL DE Heteropsis spp. Kunth (CIPÓ TITICA) NA FLORESTA NACIONAL DO TAPAJÓS, PARÁ-BRASIL}

RESUMO - O presente estudo foi realizado com o objetivo de analisar os aspectos ecológicos de Heteropsis spp. Kunth (cipó titica) em uma área mantida sob condição de manejo florestal. O estudo foi conduzido na Floresta Nacional do Tapajós, no estado do Pará, Brasil, na Unidade de Produção Anual 11. Para o inventário das árvores hospedeiras de cipó titica foram percorridas 206,25 ha. Os parâmetros registrados foram: diâmetro a 1,30 m do solo (DAP), altura total (Ht), nome regional e coordenadas geográficas. Foram contabilizadas as raízes aéreas maduras e imaturas do cipó titica e coletadas e mensuradas a massa das raízes maduras com e sem casca. Foi relacionada a densidade das árvores hospedeiras em diferentes centros de classes de DAP e Ht. Foi feita a relação do DAP e Ht das árvores hospedeiras com a massa das raízes maduras com casca do cipó titica. A distribuição espacial foi feita com base na função K de Ripley. Foram inventariadas 337 árvores como hospedeiras, com densidade média de 1,65 árv.ha ${ }^{-1}$, distribuidas em 88 espécies. Árvores com DAP $<30$ $\mathrm{cm}$ são as que hospedam mais plantas de cipó titica. Árvores com $10 \mathrm{~m} \leq \mathrm{Ht}<15 \mathrm{~m}$ hospedam mais plantas de cipó titica, quando comparadas às árvores de $H t \geq 25 \mathrm{~m}$. Arvores com maior DAP e Ht são as que apresentam maior quantidade de raízes de cipó titica. Os indivíduos de cipó titica apresentaram 585 raízes.ha ${ }^{-1}$, levando a uma produção média de 2,1 kg. ha-1 de cipó titica com casca, declinando após o beneficiamento para 0,6 kg. ha-1. Concluiu-se que o cipó titica não tem preferência por espécie arbórea hospedeira e que a distribuição espacial tende a ser agregada.

Palavras-Chave: Hemiepifita; Extrativismo; Distribuição espacial. 


\section{INTRODUCTION}

Tropical forests have a large diversity of nonwood forest products (NWFPs) that can be of animal or plant origin (non-woody), which are found in native and planted forests and in agroecosystems (Wallace et al., 2005; Elias, 2016; Santos, 2016). Among the NWFPs found in these forests is the titica vine (Heteropsis spp. Kunth), which has resistant fiber and is easily worked and is used in artisanal crafts (baskets, domestic utensils and furniture, among others), and also as rope used for securing structures in building construction (Balcázar-Vargas et al., 2015).

The titica vine is found in Brazil, the Guianas, Peru, Venezuela and Colombia. In Brazil it is found predominantly in the Amazon basin and the Atlantic rain forest, and the state with the greatest predominance of this species is Amapá, followed by Pará, Amazonas and Rondônia (Bentes-Gama et al., 2007; Soares et al., 2009).

Products made from the titica vine are found in open-air markets in the North region and are used in the furniture industry to make rustic items in the South and Southeast regions of Brazil (Elias, 2016; Santos, 2016). There is a significant market demand for this raw material which could compromise the abundance of this species in native forests.

According to the red list of species threatened with extinction, elaborated by the National Center for the Conservation of Flora, the titica vine is in a state of vulnerability because there has been a reduction in its populations due to extractivism. For example, in areas that are more easily accessible there has been a reduction in the quantity of roots available for harvest. As a consequence, harvesters have begun harvesting these roots in areas that are farther away and of more difficult access, and in these more distant areas harvesters have shown less preoccupation with collecting only mature roots and now collect even the roots of young individuals (CNCFlora, 2012).

Some sustainable use federal conservation units define the titica vine as a protected species, as in the Adolpho Ducke Forest Reserve in the state of Amazonas, and the Alto Juruá Extractivist Reserve in Acre, with the objective of guaranteeing the perpetuation of the species (CNCFlora, 2012).
However, in the Tapajós National Forest (FLONA Tapajós) in the state of Pará, studies on this species are still incipient, and more information on the ecology of this species and its establishment on host trees is needed to define management and conservation parameters in natural environments (Bentes-Gama et al., 2007; Costa et al., 2019).

It is important to emphasize that in the state of Pará there is no specific legislation for the management of the titica vine, and this makes this species even more susceptible to predatory actions, in contrast to the states of Amapá and Amazonas, which have laws that regulate activities using the titica vine in order to minimize the impacts on its natural populations (Amapá, 2001; 2002; 2009; Amazonas, 2008; Santos et al., 2018).

In this context, the focus of this study was the following scientific question: how does the titica vine respond to forest management activities? The hypothesis that was tested was that the titica vine has no preference for the species of tree is uses as a host and does not present a defined pattern of spatial distribution. This hypothesis is justified based on the vast number of species that serve as support for the titica vine and on observations by extractivists that there does not appear to be a pattern in its spatial distribution (Ferreira and Bentes-Gama, 2005; Bentes-Gama et al., 2010). Therefore, this study was conducted with the objective of analyzing the ecological aspects of the titica vine in an area subjected to forest management.

\section{MATERIAL AND METHODS}

\subsection{Study area}

This study was conducted in an area of forest management (AMF) that is administered by the mixed cooperative of the FLONA Tapajós (COOMFLONA), in the FLONA Tapajós at km 117 $\left(03^{\circ} 20^{\prime} 57.54\right.$ " $\mathrm{S}$ and $55^{\circ} 01^{\prime} 50.62$ " $\left.\mathrm{W}\right)$ along the BR 163 highway (Santarém-Cuiabá). The FLONA Tapajós is a federal sustainable use Conservation Unit (CU) located in the western region of the state of Pará and which contains all or part of the municipalities of Belterra, Rurópolis and Placas, with an area of approximately 527,000 hectares and contains 25 communities (ICMBio, 2016).

Revista Árvore 2019;43(6):e430603 
The climate in the FLONA Tapajós is classified as Am in the Köppen Geiger system, which is tropical humid with annual temperature variation of less than $5^{\circ} \mathrm{C}$, and average annual temperature of $25.5^{\circ} \mathrm{C}$, average air relative humidity of $88 \%$ and average annual rainfall of $1,820 \mathrm{~mm}$ (IBAMA, 2004). The predominant soil is a yellow dystrophic Oxisol with widely varying textures including some large areas with very sandy soil, generally very deep, acidic, and friable (Espírito Santo et al., 2005). The vegetation is classified as dense ombrophilous forest with predominance of large trees and an abundance of woody vines, palms, and epiphytes (IBGE, 2012).

\subsection{Data collection}

Data were collected in two work units (UTs; numbers 3 and 15), of the Annual Production Unit (UPA 11), which was managed in 2016. At each locale, leaf and fruit samples from the titica vine were collected, and exsiccatae were made and these were deposited in the herbarium of the Federal Rural University of Amazonia (UFRA).

The UT 3 has a size of $1,000 \mathrm{~m} \times 1,000 \mathrm{~m}$ with clay soil and had $2,204.37 \mathrm{~m}^{3}$ of wood harvested. The UT 15 has a size of $1,000 \mathrm{~m}$ x 1,250 $\mathrm{m}$ with sandy soil and had $1,578.50 \mathrm{~m}^{3}$ of wood harvested. Each UT is divided into quadrants of $250 \mathrm{~m} \times 250 \mathrm{~m}$, and these are the sampling units.

For the inventory of host trees of the titica vine we sampled 14 quadrants in UT 3 (87.5 ha) and 19 quadrants in UT 15 (118.75 ha), totaling 33 quadrants which covered 206.25 ha of sampled area.

The parameters recorded in the inventory of trees that are hosts to titica vine and that had diameter at breast height $(\mathrm{DBH}) \geq 10 \mathrm{~cm}$ at $1.3 \mathrm{~m}$ above the soil surface were $\mathrm{DBH}$, total height $(\mathrm{Ht})$, regional name and geographic coordinates (latitude and longitude).

Aerial roots were quantified in two groups: mature with brown bark and that did not break easily, and immature with green bark and that were easily broken. Immature roots are generally not collected for artisan crafts because of a lack of rigidness, so these roots were not collected in this study. Mature roots were collected for each host and weighed $(\mathrm{kg})$ using a digital hook balance, and this was done in the forest so that the mass of the roots was not influenced by loss of humidity.

\subsection{Characterization of host species and production of titica vine}

Trees hosting titica vine were identified by regional name in the field by an experienced parabotanist that also participates in the annual inventory done by COOMFLONA. The taxonomic classification system adopted was the Angiosperm Phylogeny Group - APG IV (APG, 2016). The authors of the species were confirmed by consulting the site Flora do Brasil (JBRJ, 2019). All host trees were counted and grouped according to their botanical families.

In order to test whether titica vine displays a preference for a specific range of host tree diameters and heights, the density of individuals in different classes of diameter and height were used to establish a relationship. (Bentes-Gama et al., 2010).

To determine if diameter and height of host trees influence the production of titica vine, 15 trees of different sizes of height and diameter were selected in each DBH and height class, and these were classified in small, medium, and large size classes (Table 1).

\subsection{Spatial distribution}

The spatial distribution of titica vine was analyzed by applying the Ripley $\mathrm{K}$ function, an efficient statistical tool in population ecology studies that simultaneously takes into account different scales and distances, and also includes the isotropic border principle (Ripley, 1981; Silva, 2015).

By conducting 99 Monte Carlo simulations the confidence envelopes were defined with a probability of $99 \%$, and this process indicates the acceptance of the hypothesis of a random spatial pattern. The extreme limits of the envelopes are represented by the

Table 1 - Size classes of host trees selected for the calculation of the ratio between the dendrometric variables and biomass production of Heteropsis spp. Kunth (titica vine), Tapajós, National Forest, Pará.

Tabela 1 - Classes de tamanho das árvores hospedeiras selecionadas para fazer a relação das variáveis dendrométricas com a produção de massa de Heteropsis spp. Kunth (cipó titica), Floresta Nacional do Tapajós,

\begin{tabular}{ccc} 
& & \\
\hline Size & DBH $(\mathrm{cm})$ & Total height $(\mathrm{m})$ \\
\hline Small & $10 \mathrm{~cm} \leq \mathrm{DBH}<40 \mathrm{~cm}$ & $5 \mathrm{~m} \leq \mathrm{Ht}<15 \mathrm{~m}$ \\
Medium & $40 \mathrm{~cm} \leq \mathrm{DBH}<70 \mathrm{~cm}$ & $15 \mathrm{~m} \leq \mathrm{Ht}<25 \mathrm{~m}$ \\
Large & $\mathrm{DBH} \geq 70 \mathrm{~cm}$ & $\mathrm{Ht} \geq 25 \mathrm{~m}$ \\
\hline
\end{tabular}

Revista Árvore 2019;43(6):e430603 
amplitude of the $\mathrm{K}$ values that result from simulations for each distance $(\mathrm{S})$. In order to simplify the analysis, the $K$ values were transformed into $L^{\wedge}(S)$, in which the axes of the abscissas correspond to the distances, and the ordinates the transformed values of the function $\mathrm{K}$ (Ripley, 1979).

The null hypothesis of the Ripley $\mathrm{K}$ function is that of Completely Random Spatial (CRS) distribution. In the case that this hypothesis is refuted then there are two options: aggregation or uniformity, when the values fall outside of the limit of the envelopes. The limits of the confidence envelope are identified by the pointed lines, with one positive and the other negative. The $\mathrm{K}$ value is identified by the continuous line, and when it falls above the upper line of the confidence envelope this indicates an aggregated distribution; when it is in the interior of the envelope this signifies a random pattern, and when it is below the lower line this indicates a uniform distribution (Vieira, 2015).

\subsection{Data analysis}

The data were compiled using the program Excel for Windows 2013, and statistical analyses were done using R version 3.1.2 (R Development Core Team, 2014), with the univariate $K$ function estimated using the Splancs package (Rowlingson and Diggle, 2014).

\section{RESULTS}

\subsection{Characterization of host species and production of titica vine}

The species of the genus Heteropsis identified in the study area, popularly denominated as titica vine, were Heteropsis flexuosa (Kunth) G.S.Buting and Heteropsis steyermarkii G.S.Buting. Exsiccates of these species are deposited in the UFRA herbarium under numbers 3,284 and 3,285, respectively.

A total of 337 trees hosting the titica vine were identified and measured, with a density of 0.2 to 3.8 trees.ha- $^{-1}$ (average of 1.65 trees.ha $^{-1}$ ), distributed in 88 species belonging to 35 families.

The botanical families that were most prevalent as hosts for the titica vine were Fabaceae, Lecythidaceae, Sapotaceae, Burseraceae, Lauraceae and Moraceae, corresponding to $73 \%$ of the total.

The host species that had the greatest quantity (kg) of mature roots of titica vine were Pouteria cladantha Sandwith (3,368 kg.ha-1), Chamaecrista scleroxylon (Ducke) H.S.Irwin \& Barneby (3,354 kg.ha-1), Eschweilera sp. Mart. ex DC. (3,244 kg.ha-1) and Lecythis lurida (Miers) S.A.Mori (3,087 kg.ha-1).

Titica vine was found on trees that ranged in diameter from $10.19 \mathrm{~cm}$ to $189.39 \mathrm{~cm}$. However, as shown in Figure 1, smaller diameter trees $(\mathrm{DBH}<$ $30 \mathrm{~cm}$ ) host more titica vines than do larger diameter trees $(\mathrm{DBH} \geq 65 \mathrm{~cm})$.

With respect to host tree height and titica vine presence, there was a relationship with trees between $7 \mathrm{~m}$ to $35 \mathrm{~m}$. Figure 2 shows that trees between $10 \mathrm{~m}$ $\leq \mathrm{Ht}<15 \mathrm{~m}$ host more titica vines when compared to trees with $\mathrm{Ht} \geq 25 \mathrm{~m}$.

Figure 3 shows that larger trees $(D B H \geq 70 \mathrm{~cm}$ and $\mathrm{Ht} \geq 25 \mathrm{~m}$ ) are those that have a greater quantity of titica vine roots $(\mathrm{kg})$ when compared to smaller trees $(\mathrm{DBH} \geq 10 \mathrm{~cm}$ and $\mathrm{Ht} \geq 5 \mathrm{~m})$.

The sampled titica vine in this study had a total of 585 roots.ha $^{-1}$, and average production of 2.1 kg.ha ${ }^{-1}$ titica vine with bark. After loss of humidity and removal of the bark production declined to 0.6 $\mathrm{kg} \cdot \mathrm{ha}^{-1}$ with respect to the mass of mature roots that were collected.

\subsection{Spatial distribution}

In Figure 4 the results for the analysis of spatial distribution are shown for the two sampled production

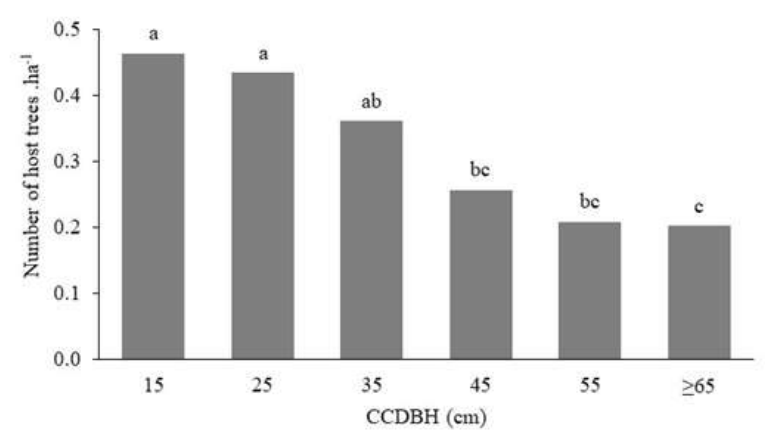

Figure 1 - Density of Heteropsis spp. Kunth (titica vine) host trees by DBH Class Center (CCDBH), Tapajós National Forest, Pará. Averages followed by the same letter are not different according to the Kruskal-Wallis test at 95\% probability $\left(p\right.$-value $\left.=9.9488 \times 10^{-8}\right)$.

Figura 1 - Densidade de árvores hospedeiras de Heteropsis spp. Kunth (cipó titica) por Centro de Classe de DAP (CCDAP), Floresta Nacional do Tapajós, Pará. Médias seguidas pela mesma letra não diferem entre si, de acordo com o Teste de Kruskal-Wallis a 95\% de probabilidade $\left(p\right.$-valor $\left.=9,9488 \times 10^{-8}\right)$. 


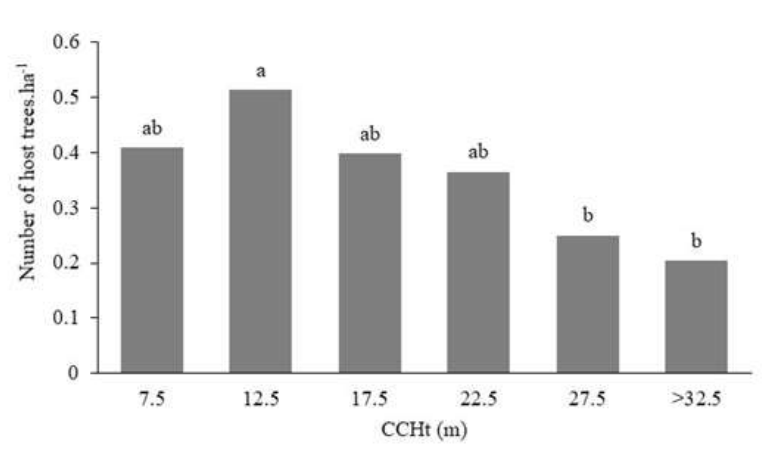

Figure 2 - Density of Heteropsis spp. Kunth (titica vine) host trees by Height Class Center (CCHt), Tapajós National Forest, Pará. Averages followed by the same letter are not different according to the Kruskal-Wallis test at 95\% probability $(p-$ value $=0.0059)$.

Figura 2 - Densidade de árvores hospedeiras de Heteropsis spp. Kunth (cipó titica) por Centro de Classe de Altura (CCHt), Floresta Nacional do Tapajós, Pará. Médias seguidas pela mesma letra não diferem entre si, de acordo com o Teste de Kruskal-Wallis a 95\% de probabilidade ( $p$-valor $=0,0059)$.
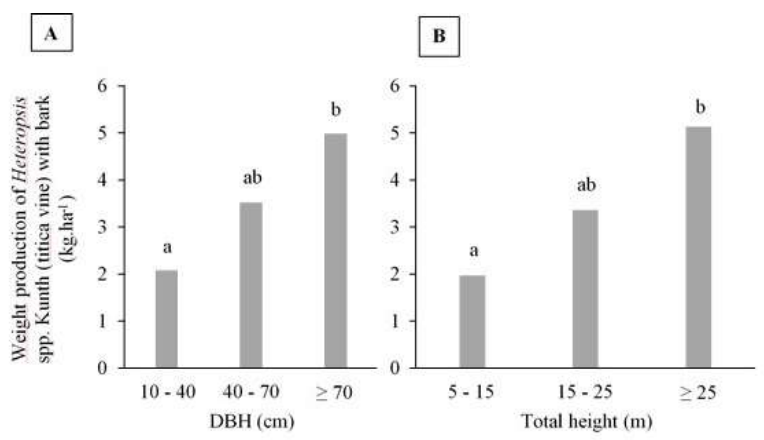

Figure 3 - Ratio of biomass production of Heteropsis spp. Kunth (titica vine) with bark $\left(\mathrm{kg} \cdot \mathrm{ha}^{-1}\right)$, with host tree size, taking into account DBH and total height, Tapajós National Forest, Pará. A: Averages followed by the same letter are not different according to the Tukey Test at $95 \%$ probability $(p$-value $=<0.01)$. B: Averages followed by the same letter are not different according to the KruskalWallis test at $95 \%$ probability ( $p$-value $=<0.0001)$.

Figura 3 - Relação da produção de massa de Heteropsis spp. Kunth (cipó titica) com casca (kg.ha-1), com porte das árvores hospedeiras, levando em consideração DAP e altura total, Floresta Nacional do Tapajós, Pará. Em que A: Médias seguidas pela mesma letra não diferem entre si, de acordo com o Teste Tukey a 95\% de probabilidade ( $p$-valor $=<0,01)$. B: Médias seguidas pela mesma letra não diferem entre si, de acordo com o Teste de KruskalWallis a 95\% de probabilidade ( -valor $=<0,0001)$.

units. The first graph shows the results for UT 3 wherein titica vine presented an aggregated spatial distribution although at points $150 \mathrm{~m}$ and $450 \mathrm{~m}$ there is a small tendency toward randomness. In UT 15 the spatial distribution was aggregated up to $350 \mathrm{~m}$, and from this point onward it was random.
The soil at UT 3 was clayey, but at UT 15 it was sandy, therefore, further studies including soil analyses are needed in order to determine if this variable influences the distribution of the titica vine.

The aggregate distribution dominated the spatial arrangement of titica vine at these research sites, and the mode of seed dispersion is indicative of this behavior.

\section{DISCUSSION}

\subsection{Characterization of host species and production of titica vine}

The species Heteropsis flexuosa (Kunth) G.S.Buting and Heteropsis steyermarkii G.S.Buting are among the most common in the Amazon of the genus Heteropsis, however, H. flexuosa has a tendency to occupy clay soils while $H$. steyermarkii is more prevalent on sandy soils (Morais, 2008).

In the sites evaluated in the present study there was a low occurrence of titica vine when compared to other sites where similar inventories have been done (Hoffman, 1997; Plowden et al., 2003; BentesGamaet al., 2013; Klauberg et al., 2016). For large areas, similar to those in the present study, there is a reduction in the density of hosts of titica vine, as observed in the Jaú National Park in the state of Amazonas where only 1 to 5 trees.ha $^{-1}$ that are hosts of titica vine were found (Durigan, 1998).

With respect to the botanical families that are most represented for trees that are hosts of titica vine, Canalez (2009) affirms that the Araceae family in terra firme forest is most frequently represented by tree species in the families Myristicaceae, Lecytidaceae and Sapatoceae. However, the last two families mentioned above are predominant in the sites of the present study. The family Lecytidaceae was the one that had the largest number of hosts for Heteropsis in the Ducke Reserve in the State of Amazonas (Morais, 2008).

In the present study the relationship between the host species that had the greatest number of productive titica vines was highlighted because commercialization of raw material depends on the quantity of fiber that is collected (Ferreira and Bentes-Gama, 2005). In general, studies have reported this relationship as the percentage of association of this hemiepiphyte 


\section{UT 3}

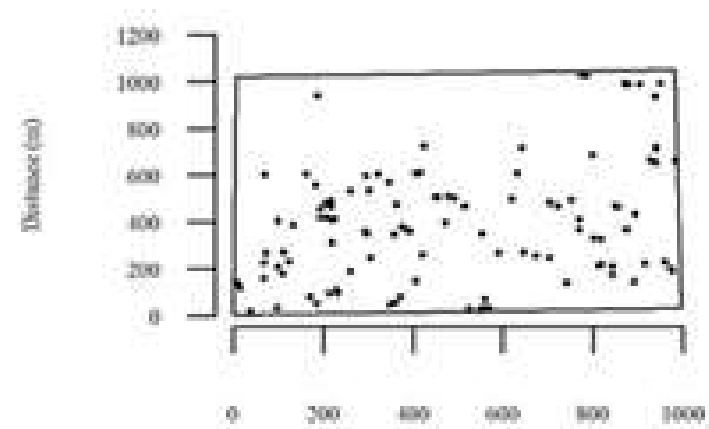

Dhesereites

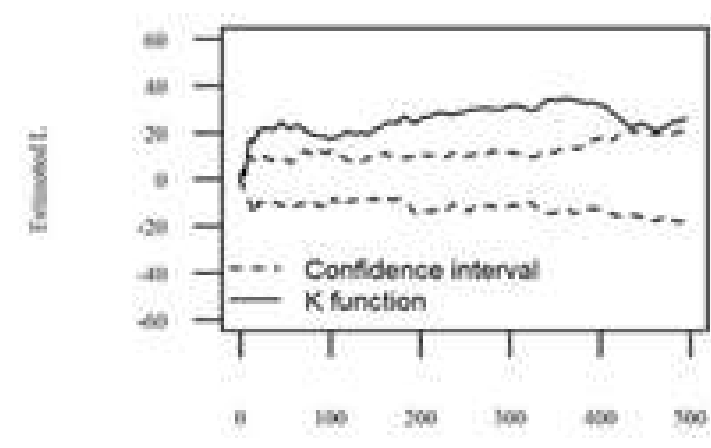

Distonce iny

\section{UT 15}

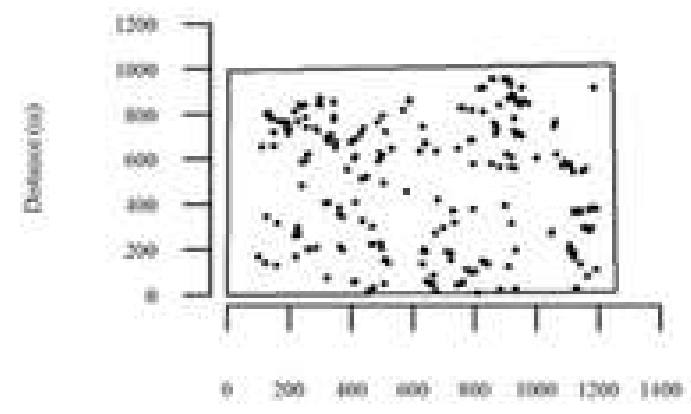

Shankebs

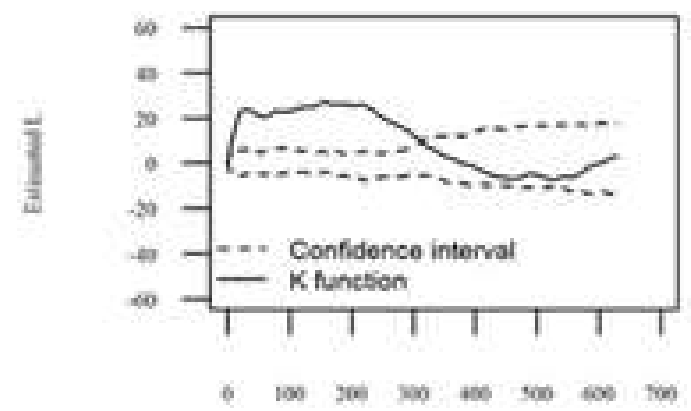

Didasecial

Figure 4 - Spatial distribution pattern of Heteropsis spp. Kunth (titica vine) in the Work Units (UT 3 and 15) of UPA 11, Tapajós National Forest, Pará

Figura 4 - Padrão de distribuição espacial de Heteropsis spp. Kunth (cipó titica) nas Unidades de Trabalho (UT 3 e 15) da UPA 11, Floresta Nacional do Tapajós, Pará.

with the host tree. In a study done by Bentes-Gama et al. (2010), the most frequent host species of titica vine were Eschweilera coriacea (DC.) S.A.Mori, Protium sp. Burm f., Licania membranacea Sagot ex Laness., Annona exsucca DC. e Pouteria bilocularis (H.K.A.Wink1.) Baehni, because these were the most frequent species found at this site (Vieira et al., 2002).

For the relationship between the titica vine and tree diameter, Morais (2008), found a positive relationship between individuals of the genus Heteropsis and host tree diameter; however, this author also observed that in spite of the fact that Heteropsis spp. colonized trees from all diameter classes, they were more frequent on trees with $\mathrm{DBH}>30 \mathrm{~cm}$. Similar results were reported by Knab-Vispo et al. (2003), but in contrast Plowden et al. (2003), reported that most individuals were associated with host trees of $\mathrm{DBH}<10 \mathrm{~cm}$.

The analysis of host tree height showed that the development of titica vine is facilitated on trees of intermediate height (Knab-Vispo et al., 2003; Bentes-

Revista Árvore 2019;43(6):e430603 
Gama et al., 2013). For example, five species of the genus Heteropsis were shown to occupy principally the understorey ( $0-5 \mathrm{~m}$ height $)$ and below the canopy (5 - $10 \mathrm{~m}$ height) in a terra firme forest (Morais, 2008).

The production of titica vine was greatest on trees with a larger surface area for fixation. BálcázarVargas et al. (2015) affirm that the height of the host species is a good indicator for growth of feeder roots of adult individuals of titica vine and that the higher it climbs in the tree the greater the possibility of survival, number of leaves, branches, and roots.

Similar results for titica vine production to those of the present study were related by Plowden et al. (2003) in their study done in the eastern Brazilian Amazon wherein they reported 544 roots. $\mathrm{ha}^{-1}$. Klauberg (2014), in spite of having observed a high density of titica vine in Paragominas-PA, found results that were inferior to those of the present study reporting only 62 roots.ha- ${ }^{-1}$.

\subsection{Spatial distribution}

The spatial distribution of a forest population can be represented in three ways: random - when the position of an individual is not influenced by other individuals, and therefore it is possible to find any individual at any point in the area; aggregated individuals tend to occur in groups, therefore their presence is influenced by other individuals in the area; and regular - distance is equivalent between individuals and the presence of one precludes the presence of the other (Odum, 1986; Vieira, 2015).

The differences in spatial distribution observed in the two areas possibly occurred due to a greater number of host trees in UT $15(\mathrm{n}=225)$, and that this UT has a larger area than UT 3. Another factor that could have cause the titica vine to display two types of spatial distribution is that it shows no preference for a specific host species and that there is a large range of host species with distinct forms and distributions in the area (Knab-Vispo et al., 2003).

Silva (2015), affirm that the pattern of spatial distribution of a population can be affected by factors that are intrinsic to a species, such as aspects of reproduction, and social and coactive habits, and also extrinsic factors such as external environmental variables of wind, light intensity and soil conditions. According to Antonini and Nunes-Freitas (2004), species whose seed is dispersed by animals are generally present in an aggregated form in forests, and in this case the titica vine is dispersed by birds and monkeys (Morais, 2008).

Collectors that extract titica vine in the state of Amapá relate that there is no pattern of spatial distribution because in some areas individuals are widely dispersed, while in others they are highly concentrated (Ferreira and Bentes-Gama, 2005). This information comes from empirical knowledge of traditional populations and has great value as a complement to scientific knowledge, however more ecological studies are needed on the spatial distribution of Heteropsis spp in order to aid in management activities.

\section{CONCLUSION}

The hypothesis that Heteropsis spp. (titica vine) does not have a preference for specific species of host trees was affirmed, however the frequency of titica vine is greater on smaller trees, and vine production is greater for taller trees with larger diameter. Furthermore, this study showed that the spatial distribution of titica vine tends to be aggregated.

\section{REFERENCES}

Amapá. Lei no 0631, de 21 de nov. de 2001. Dispõe sobre procedimentos para a extração, transporte e comercialização de espécies vegetais produtoras de fibra tipo Cipó Titica (Heteropsis spp), Cipó Cebolão (Clusia spp) e similares em todo o Estado do Amapá e dá outras providências. Disponível em: < http://www.al.ap.gov.br/ver_texto_lei. php?iddocumento $=16832>$. Acesso em: 28 ago. 2017.

Amapá. Resolução COEMA nº 05, de 29 de abr. de 2002. Dispõe sobre critérios e diretrizes para a extração racional de espécies produtoras de fibra tipo Cipó Titica (Heteropsis spp), Cipó Cebolão (Clusia spp) e similares em todo o Estado do Amapá e dá outras providências. Disponível em: < http://www. sema.ap.gov.br/interno.php?dm=707>. Acesso em: 27 ago. 2017.

Amapá. Resolução COEMA n ${ }^{\circ}$ 13, de 30 de jul. de 2009. Dispõe sobre os procedimentos técnicos para elaboração, apresentação, execução e avaliação técnica de Planos de Manejo Florestal de Cipós. 
Disponível em: < http://www.sema.ap.gov.br/interno. php?dm=707>. Acesso em: 27 ago. 2017.

Amazonas. Instrução Normativa $n^{\circ} 01$, de 11 de Fevereiro de 2008. Dispõe sobre procedimentos básicos para o licenciamento ambiental do manejo do cipó-titica (Heteropsis flexuosa), cipó timbóaçú ou titicão (Heteropsis jenmanii) e cipó-ambé (Philodendron sp.) e similares, para fins comerciais, baseado nas práticas tradicionais de coleta sustentável e nos resultados das pesquisas científicas. Disponível em: < http:/www.gret.org/static/cdrom/ floresta_viva_amazonas/Files/2.1.1_4_0802 in02_2002_pmfspe.pdf $>$. Acesso em: 27 ago. 2017.

Angiosperm Phylogeny Group - APG. An update of the Angiosperm Phylogeny Group classification for the orders and families of flowering plants: APG IV. Botanical Journal of the Linnean Society. 2016;181(1):1-20.

Antonini RD, Nunes-Freitas AF. Estrutura populacional e distribuição espacial de Miconia prasina DC. (Melastomataceae) em duas áreas de Floresta Atlântica na Ilha Grande, RJ, Sudeste do Brasil. Acta Botonica Brasilica. 2004;18(3):671-676.

Balcázar-Vargas MP, van Andel TR, Westers P, Zuidema PA. What drives the vital ratesof secondary hemiepiphytes? A first assessment for thre espécies of Heteropsis (Araceae) in the Colombian Amazon. Journal of Tropical Ecology. 2015;31(3):251-265.

Bentes-Gama MM, Vieira AH, Rocha RB, Silva APFF. Principais espécies arbóreas hospedeiras do cipó-titica (Heteropsis flexuosa (H.B.K.) G.S. Bunting). Porto Velho: Embrapa; 2007. (Circular Técnica, 96).

Bentes-Gama MM, Vieira AH, Rocha RB. Recursos florestais não-madeireiros da Amazônia ocidental brasileira: Cipó-titica (Heteropsis flexuosa (Kunth) G. S. Bunting, Araceae). Revista Forestal Latinoamericana. 2010;25(1):81-92.

Bentes-Gama MM, Vieira AH, Rocha RB. Ecological features of titica vine (Heteropsis flexuosa (Kunth) GS Bunting) in Rondônia State, Northwest Brazilian Amazon. Annals of the Brazilian Academy of Sciences. 2013;85(3):1117-1125.

Canalez GG. Produtos Florestais Não Madeireiros: aráceas epífitas da reserva extrativista Auatí-Paraná.
[Dissertação - Mestrado em Ciências Florestais Tropicais]. Manaus (AM): Instituto Nacional de Pesquisas Amazônia - Universidade Federal do Amazonas; 2009.

Centro Nacional de Conservação da Flora CNCFlora. Heteropsis flexuosa - In Lista Vermelha da flora brasileira versão 2012. 2 Centro Nacional de Conservação da Flora. Disponível em: <http:// cncflora.jbrj.gov.br/portal/pt-br/profile/Heteropsis flexuosa>. Acesso em: 13 junho 2018.

Costa DL, Santos MF, Melo LO, Gama JRV, Bezerra TG, Lima BA, et al. S. Estoque de árvores em uma área não manejada na Floresta Nacional do Tapajós, PA. Advances in Forestry Science. 2019;6(2):623-630.

Durigan CC. Biologia e extrativismo do cipó-titica (Heteropsis spp.- Araceae) - estudo para avaliação dos impactos da coleta sobre a vegetação de terra-firme no Parque Nacional do Jaú. [Dissertação - Mestrado em biologia tropical e recursos naturais]. Manaus (AM): Instituto Nacional de Pesquisas Amazônia Universidade Federal do Amazonas; 1998.

Elias GA, Sntos R. Produtos florestais não madeireiros e valor potencial de exploração sustentável da floresta atlântica no sul de Santa Catarina. Revista Ciência Florestal. 2016;26(1):249-262.

Espírito Santo FDB, Shimabukuro YE, Aragão LEOC, Machado ELM. Análise da composição florística e fitossociológica da Floresta Nacional do Tapajós com o apoio geográfico de imagens de satélites. Revista Acta Amazônica. 2005;35(2):155-173.

Ferreira MGR, Bentes-Gama MM. Ecologia e formas de aproveitamento econômico do cipó-titica (Heteropsis flexuosa (H. B. K.) G. S. Bunting). Porto Velho: Embrapa Rondônia, 2005. 22 p. (Boletim Técnico, 95).

Hoffman B. The biology and use of nibbi Heteropsis flexuosa (Araceae): the source of an aerial root fiber product in Guyana. [ Thesis - Master in Sciences in Biological Sciences]. Miami - Florida. Florida International University; 1997.

Instituto Brasileiro de Meio Ambiente e Recursos Renováveis - IBAMA. Floresta Nacional do Tapajós: Plano de Manejo. Brasília; 2004. v. 1, p.580.

Instituto Brasileiro de Geografia e Estatística - IBGE.

Revista Árvore 2019;43(6):e430603 
Manual técnico da vegetação brasileira. 2. ed. Rio de Janeiro: 2012. 274 p. (Manuais Técnicos em Geociências).

Instituto Chico Mendes de Conservação da Biodiversidade - ICMBio. A Floresta Nacional do Tapajós. Disponível em: <http://www.icmbio.gov.br/ flonatapajos/>. Acessado em: 25 jun 2016.

Jardim Botânico do Rio de Janeiro - JBRJ. Flora do Brasil 2020 em construção. Disponível em: < http:// floradobrasil.jbrj.gov.br/>. Acesso em: 28 ago. 2019.

Klauberg C. Potencial produtivo e de manejo de dois produtos florestais não madeireiros no contexto Amazônico - o cipó titica (Heteropsis spp.) e o óleo de copaíba (Copaifera spp.). [Tese - Doutorado em Ciências]. Piracicaba (SP): Universidade de São Paulo - Escola Superior de Agricultura "Luiz de Queiroz"; 2014.

Klauberg C, Vidal E, Silva CA, Bentes MM, Hudak AT. Sampling methods for titica vine (Heteropsis spp.) inventory in a tropical forest. Annals of Forest Science. 2016;73(3):757-764.

Knab-Vispo C, Hoffman B, Moermond T, Vispo C. Ecological observations on Heteropsis spp. (Araceae) in Southern Venezuela. Economic Botany. 2003;57(3):345-353.

Morais MLCS. Sistemática e Ecologia de Heteropsis Kunth (Araceae Juss.) com destaque especial nas espécies ocorrentes na Reserva Florestal Adolpho Ducke, Manaus-Amazonas, Brasil. [Tese - Doutorado em Ciências Biológicas]. Manaus (AM): Instituto Nacional de Pesquisas da Amazônia - Universidade Federal do Amazonas; 2008.

Odum EP. Ecologia. 1. ed. Rio de Janeiro: Guanabara S.A., 1986. 434 p.

Plowden JC, Uhl C, Oliveira FA. The ecology and harvest potential of titica vine roots (Heteropsis flexuosa: Araceae) in the eastern Brazilian Amazon. Forest Ecology and Management. 2003;182(1-3):59-73.

R Development Core Team. R: a language and environment for statistical computing. Austria: R
Foundation for Statistical Computing. Available from: <http://www.R-project.org >. 2014.

Ripley BD. Tests of randomness for spatial point patterns. Journal of the Royal Statistic Society. 1979;41(3):368-374.

Ripley BD. Spatial Statistics. London: John Wiley, 1981. 252 p.

Rowlingson B, Diggle P. Splancs: spatial and space-time point pattern analysis. Austria: $\mathrm{R}$ Development Core Team ( $\mathrm{R}$ package version 2.01-15), 2014.

Santos LE, Gama JRV, Ribeiro RBS, Silva AA, Cruz GS, Rodrigues BL. Inventário de cipó titica na Floresta Nacional do Tapajós e comercialização em Santarém, Pará. Advances in Forestry Science. 2018;5(2):309-314

Silva AR. Composição, estrutura horizontal e espacial de 16 ha de floresta densa de terra-firme no estado do Amazonas. [Dissertação - Mestrado em Ciências Florestais e Ambientais]. Manaus (AM): Universidade Federal do Amazonas; 2015.

Soares ML, Mayo SJ, Croat TB, Gribel R. Two new species and a new combination in Amazonian Heteropsis (Araceae). Kew bulletin. 2009;64(2):263-270.

Vieira DS. Padrão espacial de espécies arbóreas no Baixo rio Tapajós. [Dissertação - Mestrado em Ciências Florestais]. Diamantina (MG): Universidade Federal dos Vales do Jequitinhonha e Mucuri; 2015.

Vieira AH, Martins EP, Silveira ALP, Pequeno PLL, Locatelli M. Fitossociologia de um fragmento florestal na região de Machadinho d'Oeste, RO. Porto Velho: EMBRAPA Rondônia, 2002. 16 p. (Boletim de Pesquisa e Desenvolvimento 9).

Wallace R, Pereira L, Plowden C. Cipó-titica: Heteropsis spp. In: Shanley P, Medina G. (Eds). Frutíferas e Plantas Úteis na Vida Amazônica. Belém: CIFOR, Embrapa Amazônia Oriental, Imazon; 2005. p. 75-83. 